\title{
Harvesting Semidwarf Freestanding Apple Trees with an Over-the-row Mechanical Harvester
}

\author{
D.L. Peterson, S.S. Miller, and J.D. Whitney ${ }^{1}$ \\ U.S. Department of Agriculture, Agricultural Research Service, Appalachian Fruit Research Station, 45 \\ Wiltshire Road, Kearneysville, WV 25430
}

Additional index words. Malus domestica, quality, efficiency, shaker, fruit, machine

\begin{abstract}
Three years of mechanical harvesting (shake and catch) trials with two freestanding apple (Malus domestica Borkh.) cultivars on a semidwarf rootstock (M.7a) and two training systems (central leader and open center) yielded $64 \%$ to $77 \%$ overall harvesting efficiency. Mechanically harvested 'Bisbee Delicious' apples averaged 70\% Extra Fancy and $10 \%$ Fancy grade, while two 'Golden Delicious' strains ('Smoothee' and 'Frazier Goldspur') averaged $40 \%$ Extra Fancy and $13 \%$ Fancy grade fruit. Mechanically harvesting fresh-market-quality apples from semidwarf freestanding trees was difficult and its potential limited. Cumulative yield of open-center trees was less than that of central-leader trees during the 3 years (sixth through eighth leaf) of our study. 'Golden Delicious' trees generally produced higher yields than 'Delicious' trees.
\end{abstract}

Hand-harvesting the U.S. apple crop is labor intensive, and a supply of dependable, skilled labor is a concern of the fruit industry (LaCroix, 1989; Peterson, 1992a). Brown et al. (1983) documented that $<5 \%$ of the apple crop is mechanically harvested, all of which is for processing. Excessive damage inflicted by commercial shake and catch harvesters prevents wider acceptance by the processing industry, and apples do not meet the high quality standards required by the fresh-market industry. In the past 40 years, considerable research has been directed toward developing mechanical apple harvesting equipment. Initial efforts focused on harvesting conventional low-density spreading trees 4 to $6 \mathrm{~m}$ high or more. Various prototype harvesters were developed to remove and collect fruit from these large or standard-sized trees (Diener and Adams, 1974; Markwardt et al., 1966; Millier et al., 1973; Whitney et al., 1963). Damaged fruit, primarily with severe bruises, cuts, or punctures, often exceeded $40 \%$ of the apples harvested when these machines were tested on large trees. Most of the damage was attributed to fruit falling through the canopy to the catching surface. Researchers suggested that fruit from smaller trees, possibly 2 to $3 \mathrm{~m}$ high, may be damaged less by the machines (Cain, 1971; Lakso, 1984). Several innovative machines were developed in the 1970s to harvest smaller freestanding trees (Berlage, 1973, 1982; McHugh et al., 1977) but were still not commercially acceptable because of fruit damage.

In 1980, a project was started at the Appalachian Fruit Research Station, Kearneysville, W.Va., to develop systems for mechanically harvesting fresh-market-quality apples. Emphasis was placed on adapting tree design and machine components. Conventional wisdom was that orchards would consist of semidwarf, freestanding trees at medium densities ( $\approx 500$ to 1000 trees/ha) in the near future. An over-the-row continuously moving shake and catch harvester was developed that used an impact shaker to remove fruit (Peterson and Miller, 1989a). The unit harvested trees up to $3 \mathrm{~m}$ wide and $3 \mathrm{~m}$ high spaced 2 to $4 \mathrm{~m}$ within the row. The tree trunk received three sequential impacts of increasing energy to remove fruit. Falling fruit was intercepted and deflected to conveyors by

Received for publication 18 Feb. 1994. Accepted for publication 1 July 1994. Mention of a trade name does not constitute a guarantee, warranty, or endorsement of the product. The cost of publishing this paper was defrayed in part by the payment of page charges. Under postal regulations, this paper therefore must be hereby marked advertisement solely to indicate this fact.

${ }^{1}$ Current address: Citrus Research and Education Center, 700 Experiment Station Rd., Lake Alfred, FL 33850. inclined padded catching surfaces. A series of conveyors transferred the fruit to a tilted bin filler. Five cultivars and six training systems were evaluated for their adaptability to machine harvest (Miller and Peterson, 1989; Peterson and Miller, 1989b).

Results obtained from the initial studies indicated that selected cultivars of fresh-market-quality apples could be harvested from semidwarf freestanding trees trained to an open-center system. Tree growth habit also affected the quality of mechanically harvested apples. Fruit from spur-type trees consistently graded higher than fruit of the same cultivar from nonspur-type trees. Apples from 'Delicious' trees trained to an open center consistently graded at $\approx 80 \%$ Extra Fancy and Fancy. Apples from 'Golden Delicious' trees trained to an open center rarely achieved $60 \%$ Extra Fancy and Fancy. Damage occurred during detachment and falling through the tree canopy, on the catching surfaces, during feeding into the conveyors, and during bin filling. Fruit were also lost to the ground during harvesting. The objective of this research was to examine the results of a 3-year experiment on mechanically harvesting semidwarf freestanding apple trees of two cultivars and two training systems in relation to a) freshmarket fruit quality, b) identifying sources of fruit damage, and c) harvest efficiency. An additional objective was to follow the productivity of the selected cultivars from planting through the period during which trees were subjected to mechanical harvesting to determine the influence of training system on yield.

\section{Materials and Methods}

Harvester. The same basic harvester described by Peterson and Miller (1989a) was used in this study. The inclined padded catching surfaces were replaced with a roller decelerator catching surface (Peterson, 1992b) that showed potential in laboratory tests for reducing damage (Fig. 1). From the collecting conveyors, fruit were elevated through pairs of parallel, but offset, rotating foam cylinders to an inclined flat belt. Fruit were containerized using a bin filler (Jesperson; Agritech, Woodstock, Va.). Standard 0.73$\mathrm{m}^{3}$ wooden field bins (modelET4; Smalley Packing Co., Berryville, Va.) were used. Bins of harvested apples were transported by forklift to the grading facility and stored in a dry, shaded location for 3 to 7 days at ambient temperature before grading. A sorter (Omni Sort; Durand-Wayland, LaGrange, Ga.) was used to segregate fruit by grade and weight. Fruit were graded for damage (broken skin or bruises) only and classified according to U.S. Dept. 

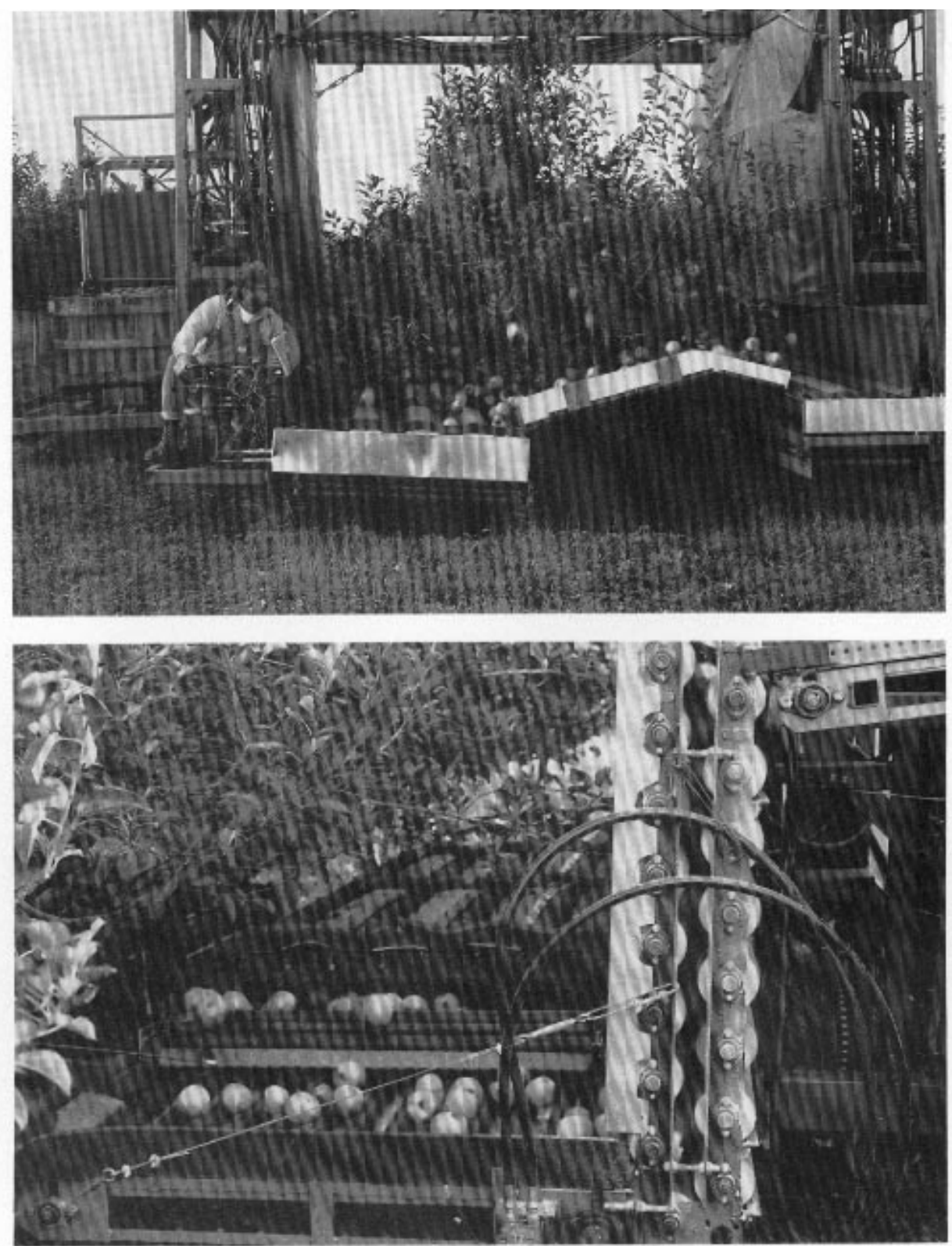

Fig. 1. U.S. Dept. of Agriculture experimental mechanical apple harvester: (top) front view and (bottom) rear view.

of Agriculture standards: Extra Fancy permitted one bruise 12.7 $\mathrm{mm}$ in diameter or several bruises with a total area not to exceed $127 \mathrm{~mm}^{2}$; Fancy permitted one bruise not to exceed $19 \mathrm{~mm}$ in diameter or several bruises with a total area not to exceed $285 \mathrm{~mm}^{2}$. The bruised category accounted for all other bruised apples. The cuts and punctures category accounted for apples with any skin breaks. Fruit with cuts or punctures and bruises were classified in the cuts and punctures category.

Tree training and culture. Mechanical-harvesting studies were conducted in a young bearing apple orchard at the Appalachian Fruit Research Station. The orchard was planted (May 1985) with 'Frazier Goldspur Golden Delicious'/M.7A (spurhabit), 'Smoothee Golden Delicious'/M.7A (standard, nonspur habit), and 'Bisbee Spur Delicious'/M.7 EMLA (spur habit). Rows were oriented north to south with an in-row spacing of $2.5 \mathrm{~m}$ and alternating between-row spacings of 4.5 and $6 \mathrm{~m}$ (761 trees/ha). Cultivars were planted in solid three-row plots of 20 trees/row. Each threerow plot was replicated six times.

All trees were headed at planting to $1 \mathrm{~m}$ and trained as freestand- ing central-leader trees as described by Heinicke (1975). Four or five shoots were selected between 86 and $100 \mathrm{~cm}$ on the leader to form the first permanent tier of scaffold branches.

Heading cuts were used in the first 3 years to aid branching and develop a strong, stiff framework required for shake and catch mechanical harvesting. Mechanical limb-spreading devices were used liberally, especially during the first 4 years, to position permanent scaffolds at $30^{\circ}$ to $45^{\circ}$ above horizontal and encourage a well-defined open canopy. Annual pruning consisted of thinning cuts once trees began to bear and had filled their allotted space. Mature central-leader (Fig. 2) trees had two tiers of permanent scaffold branches spaced $\approx 1 \mathrm{~m}$ apart. Central-leader tree height was limited to $3.0 \mathrm{~m}$ by cutting the leader back to a weak branch in the dormant season. At the end of the fourth growing season, one-half of the trees was selected for training to an open-center form (Fig. 3). The leader on selected trees was gradually dwarfed over three seasons by cutting it back to a weak side shoot, removing about one-fourth to one-third of the length of the existing leader above the first tier of permanent scaffolds. This modified leader 


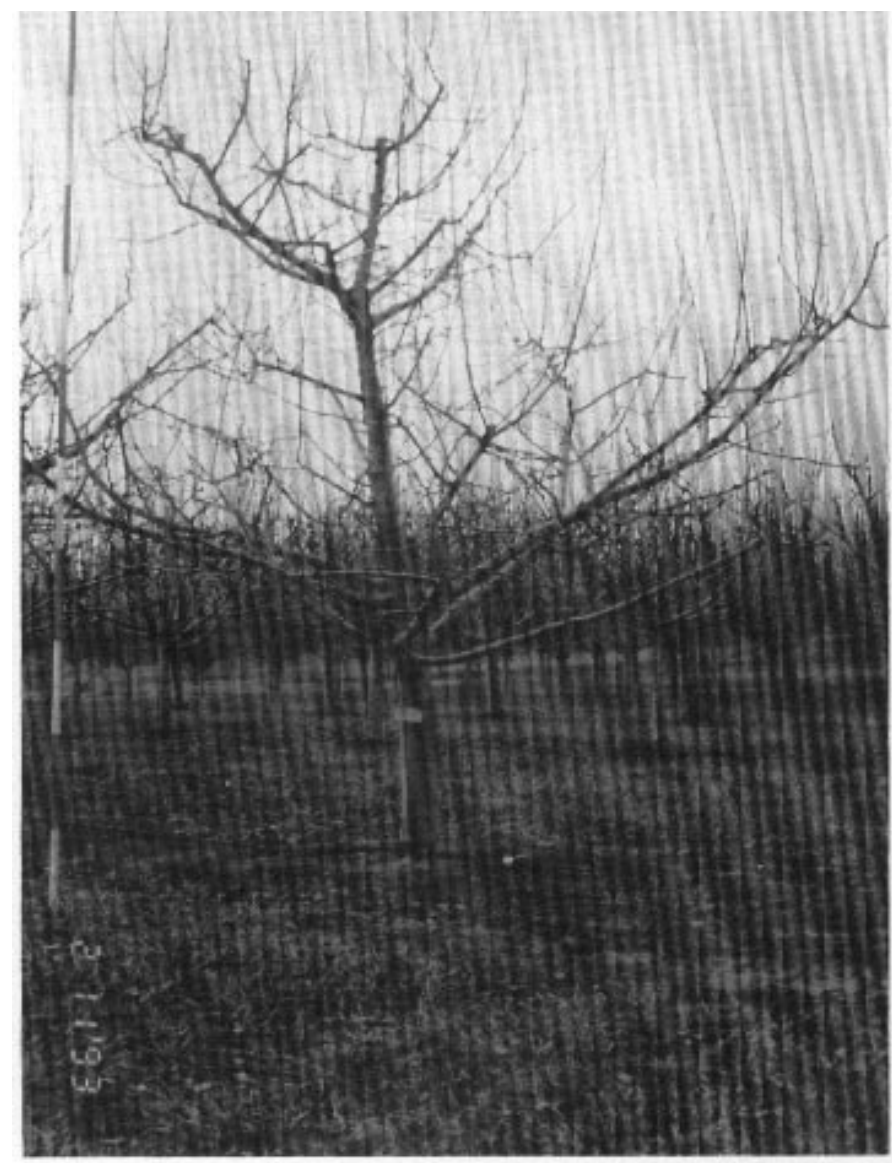

Fig. 2. Center-leader training system.

carried no fruit and was completely removed after the 1990 growing season. Mature tree height of open-center trees was $\approx 2.5$ $\mathrm{m}$ at the outer edges of the canopy. During dormant pruning, branches that might interfere with harvester movement and fruit detachment were removed.
Test procedures. The experiment was conducted during the 1990, 1991, and 1992 harvest seasons. The experimental design was a split plot, with cultivar as the main plot and training system as the subplot. Each treatment was replicated 6 times with 10 trees/ replication. Fruit quality and mechanical harvesting efficiency were evaluated. Mechanical harvesting efficiency was defined as a) preharvest loss- the proportion of the total crop that dropped to the ground before harvest plus low-hanging fruit that were hand picked before harvest to avoid interfering with machine harvest operations; b) removal efficiency - the proportion of fruit on the tree at the time of mechanical harvesting removed by impact shaking; c) collection efficiency - the proportion of fruit removed by the impact shaker collected by the mechanical harvester; $d$ ) machine efficiency - the proportion of the total crop on the tree at harvest removed and collected by the mechanical harvester; and e) harvest efficiency - the proportion of the total crop in the orchard removed and collected by the mechanical harvester. For most of our studies, the trees were impacted three times and fruit flowed through the complete harvester and were containerized in a bulk bin. Apple harvest was initiated each year when fruit starch levels and flesh pressure analysis indicated optimum maturity.

In 1992, three additional studies were conducted to determine if fruit damage was affected by a) yield differences, b) fruit location within the canopy, and c) impact energy level. These tests were conducted on 'Smoothee Golden Delicious' trained to the open-center form and used 10, single-tree replications. The fruit were collected from the rear cross conveyer instead of being allowed to go through the mechanical bin-filling procedure. To determine the effect of yield differences on damage, two tree rows were selected, one with a light crop $(29.1 \mathrm{~kg} /$ tree average $)$ and the other with a heavier crop $(57.8 \mathrm{~kg} /$ tree $)$.

We expected that, even on the open-center trees, fruit positioned above the main scaffold limbs would be damaged more than fruit growing below the main scaffold. To determine this effect, apples below $135 \mathrm{~cm}$ and with an unobstructed path to the catching surface were painted one color and apples above $135 \mathrm{~cm}$ and with an obstructed path to the catching surface were painted another color. After harvesting, these apples were segregated and graded

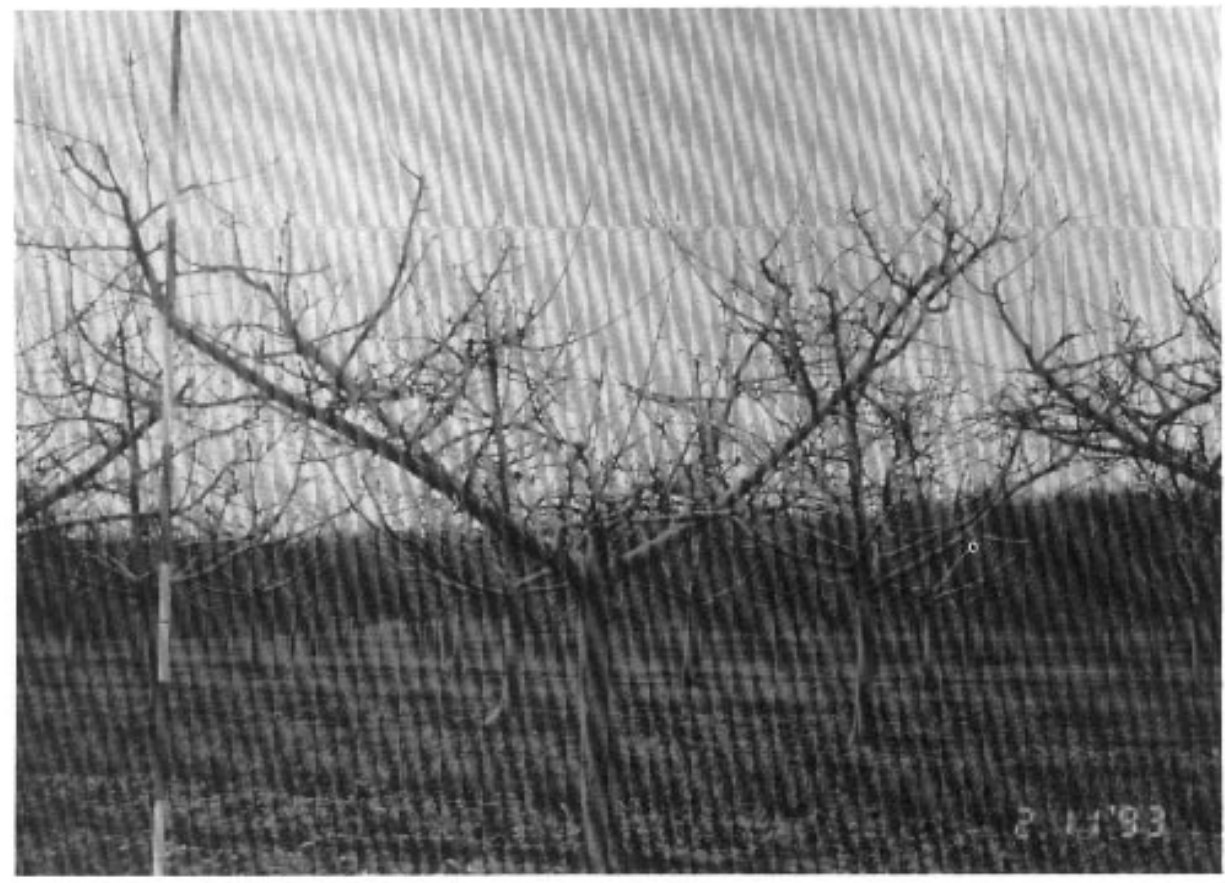

Fig. 3. Open-center training system. 
separately according to damage levels.

Normally trees were impacted three times at increasing energy levels to remove fruit. To determine if the increasing energy levels caused more damage, individual trees were harvested with either two impacts (50\% and $100 \%$ of shaker impact capacity) or four impacts $(25 \%, 50 \%, 75 \%$, and $100 \%$ of shaker impact capacity). After each impact, fruit were collected and graded separately.

\section{Results and Discussion}

Fruit quality from mechanically harvested apples was significantly affected by cultivar and harvest year (Table 1). Training system only significantly affected bruising. Previous studies (Lakso et al., 1978, Miller and Peterson, 1989; Peterson and Miller, 1989a, 1989b) had indicated that quality of mechanically harvested fruit is significantly affected by canopy design. Fruit from trees with an open canopy, such as open-center trees, consistently graded higher than fruit from more closed canopy forms, such as the centralleader trees.

In this study, mechanically harvested 'Delicious' ('Bisbee Spur Delicious') graded higher in the Extra Fancy class compared to 'Golden Delicious' ('Smoothee' or 'Frazier Goldspur'), a result that agrees with previous studies (Peterson and Miller, 1989b). This grade difference for 'Bisbee Delicious' was due to fewer apples in the bruised, and cuts and punctures categories than the
'Golden Delicious' strains (Fig. 4). 'Bisbee Spur Delicious' graded $70 \%$ Extra Fancy and 10\% Fancy, which was better than our previous research with 'Delicious' cultivars, which graded 52\% Extra Fancy and 31\% Fancy (Peterson and Miller, 1989a). The increase in the proportion of Extra Fancy grade fruit was the result of fewer small bruises and might be attributed to improvements in the catching and collecting components of the harvester that reduced the chance for fruit to fruit contact. 'Golden Delicious' bruises more easily than 'Delicious', a fact that is evident from our results.

In 1992, tests were conducted to determine if fruit damage was related to yield per tree. We suspected that the higher the yield per tree, the greater the damage from mechanical harvesting because of increased probability of fruit to fruit contact. There was little relationship between fruit damage and yield, despite the significant difference in yield (Table 2). There was a trend toward more bruising with higher yield, but there were fewer cuts and punctures. This lack of a clear trend indicated that 1) less fruit to fruit contact occurred than was expected at these two yield levels, 2) fruit to fruit contact was not important at these specific yield levels, or 3) harvester design prevented the fruit to fruit contact previously encountered, thus masking any differences due to yield.

Fruit position in the tree affected fruit damage. Apples with an unobstructed (clear) path to the catching surface were damaged less than those with an obstructed path to the catching surface (i.e., above the branches) (Table 3 ). Most of the improved quality was
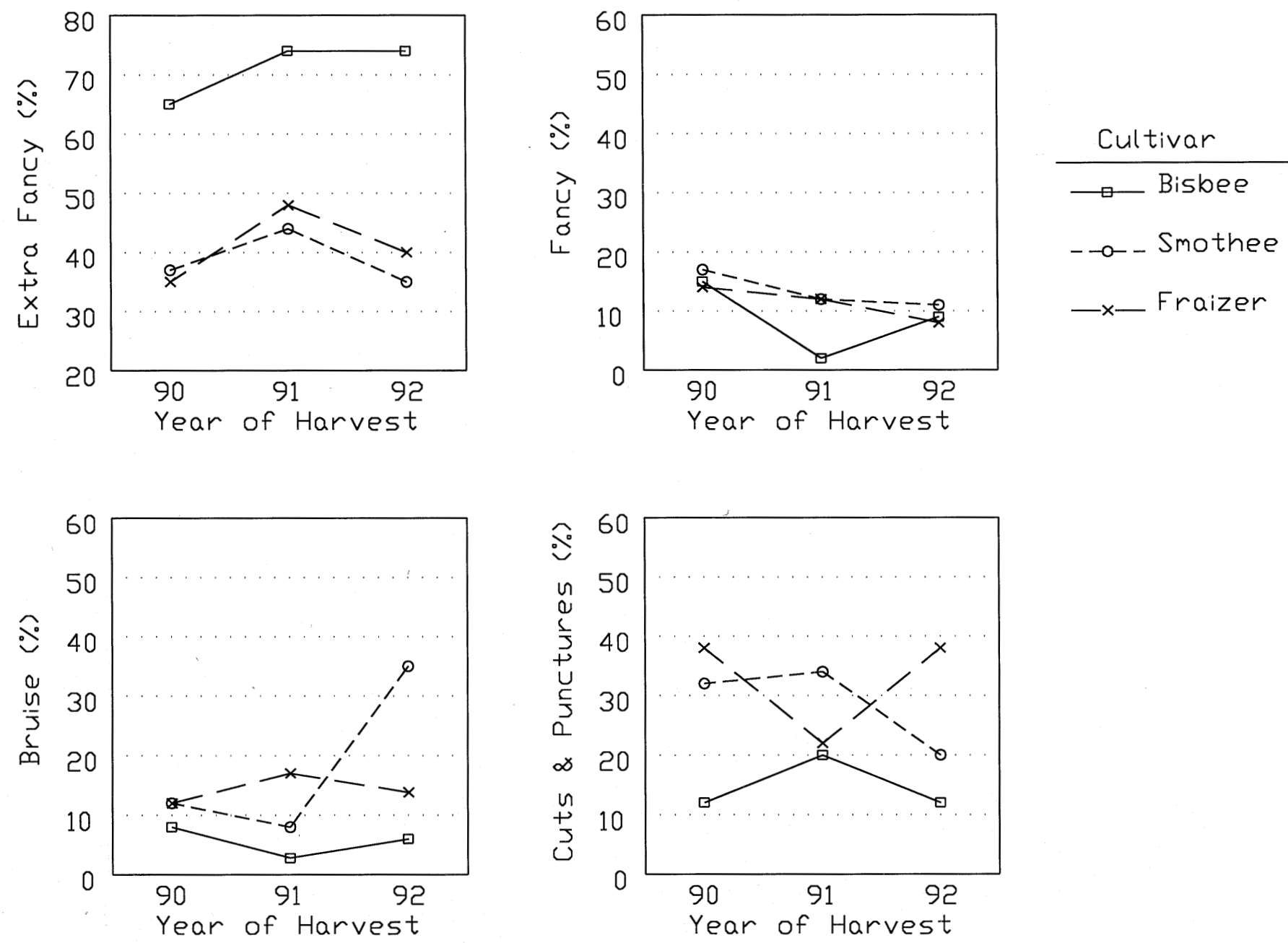

Fig. 4. Fruit quality as affected by cultivar and harvest year (system data pooled). 
Table 1. Quality of mechanically harvested apples.

\begin{tabular}{|c|c|c|c|c|c|c|}
\hline Cultivar & $\begin{array}{c}\text { Training } \\
\text { system }\end{array}$ & Year & $\begin{array}{c}\text { Extra } \\
\text { Fancy }(\%)\end{array}$ & Fancy $(\%)$ & Bruised $(\%)$ & $\begin{array}{c}\text { Cuts and } \\
\text { punctures }(\%)\end{array}$ \\
\hline \multirow[t]{6}{*}{ Bisbee Spur Delicious } & Central leader & 1990 & $62.3 \mathrm{~b}^{\mathrm{z}}$ & $15.0 \mathrm{ab}$ & $7.8 \mathrm{e}-\mathrm{h}$ & $15.0 \mathrm{fg}$ \\
\hline & & 1991 & $76.6 \mathrm{a}$ & $2.6 \mathrm{f}$ & $3.3 \mathrm{ij}$ & $17.5 \mathrm{efg}$ \\
\hline & & 1992 & $70.2 \mathrm{ab}$ & 8.9 de & $7.3 \mathrm{fgh}$ & $13.7 \mathrm{~g}$ \\
\hline & Open center & 1990 & $67.4 \mathrm{~b}$ & $15.5 \mathrm{ab}$ & $8.4 \mathrm{e}-\mathrm{h}$ & $8.7 \mathrm{~h}$ \\
\hline & & 1991 & $69.7 \mathrm{ab}$ & $2.4 \mathrm{f}$ & $2.3 \mathrm{j}$ & $25.7 \mathrm{~cd}$ \\
\hline & & 1992 & $76.6 \mathrm{a}$ & $10.0 \mathrm{cde}$ & $4.8 \mathrm{hij}$ & $8.7 \mathrm{~h}$ \\
\hline \multirow[t]{6}{*}{ Fraizer Goldspur Golden Delicious } & Central leader & 1990 & 35.2 ef & $15.9 \mathrm{ab}$ & $12.2 \mathrm{c}-\mathrm{f}$ & $36.7 \mathrm{ab}$ \\
\hline & & 1991 & $49.2 \mathrm{~cd}$ & $12.0 \mathrm{bcd}$ & $17.4 \mathrm{bc}$ & $21.3 \mathrm{de}$ \\
\hline & & 1992 & $33.3 \mathrm{f}$ & $9.3 \mathrm{de}$ & $16.5 \mathrm{bc}$ & $40.8 \mathrm{a}$ \\
\hline & Open center & 1990 & 34.9 ef & $14.8 \mathrm{abc}$ & $11.3 \mathrm{c}-\mathrm{f}$ & $39.0 \mathrm{a}$ \\
\hline & & 1991 & $46.6 \mathrm{~cd}$ & $11.8 \mathrm{bcd}$ & $16.4 \mathrm{bc}$ & $25.3 \mathrm{~cd}$ \\
\hline & & 1992 & $46.4 \mathrm{~cd}$ & $7.4 \mathrm{e}$ & $10.8 \mathrm{~d}-\mathrm{g}$ & $35.5 \mathrm{ab}$ \\
\hline \multirow[t]{6}{*}{ Smoothee Golden Delicious } & Central leader & 1990 & $33.0 \mathrm{f}$ & $18.0 \mathrm{ab}$ & $12.7 \mathrm{cde}$ & $36.4 \mathrm{ab}$ \\
\hline & & 1991 & $51.0 \mathrm{c}$ & $12.4 \mathrm{bcd}$ & 6.4 ghi & $30.3 \mathrm{bc}$ \\
\hline & & 1992 & $32.0 \mathrm{f}$ & $8.8 \mathrm{de}$ & $40.7 \mathrm{a}$ & $18.5 \mathrm{ef}$ \\
\hline & Open center & 1990 & 40.6 def & $20.1 \mathrm{a}$ & $10.6 \mathrm{~d}-\mathrm{g}$ & $28.8 \mathrm{c}$ \\
\hline & & 1991 & 39.8 def & $12.1 \mathrm{bcd}$ & 9.0 efg & $39.1 \mathrm{a}$ \\
\hline & & 1992 & 42.5 cde & $16.9 \mathrm{ab}$ & $19.1 \mathrm{~b}$ & $21.6 \mathrm{de}$ \\
\hline \multicolumn{7}{|l|}{ Analysis of variance } \\
\hline Cultivar & & & $* *$ & $* *$ & $* *$ & $* *$ \\
\hline System & & & NS & NS & $*$ & NS \\
\hline Cultivar $\times$ system & & & NS & NS & NS & NS \\
\hline Year & & & $* *$ & $* *$ & $* *$ & $* *$ \\
\hline Cultivar $\times$ year & & & NS & $* *$ & $* *$ & $* *$ \\
\hline System $\times$ year & & & $* *$ & NS & $* *$ & $* *$ \\
\hline Cultivar $\times$ system $\times$ year & & & NS & NS & NS & NS \\
\hline
\end{tabular}

$\overline{{ }^{\bar{z}} \text { Means are from raw data but data transformed with arcsin transformation for analysis. Mean separation within columns by Duncan's multiple range }}$ test, $P=0.05, \mathrm{df}=100$.

Ns,*,** Nonsignificant or significant at $P=0.05$ or 0.01 , respectively.

Table 2. Effect of yield on the quality of mechanically harvested 'Smoothee Golden Delicious' apples.

\begin{tabular}{lccccc}
\hline \hline Yield & $\begin{array}{c}\text { Avg } \\
\text { yield } \\
\text { level }\end{array}$ & $\begin{array}{c}\text { Extra } \\
\text { Fancy } \\
(\mathrm{kg} / \text { tree })\end{array}$ & $\begin{array}{c}\text { Fancy } \\
(\%)\end{array}$ & $\begin{array}{c}\text { Bruised } \\
(\%)\end{array}$ & $\begin{array}{c}\text { Cuts and } \\
\text { punctures } \\
(\%)\end{array}$ \\
\hline Low & $29.1 \mathrm{a}^{\mathrm{z}}$ & $28.6 \mathrm{a}$ & $22.3 \mathrm{a}$ & $33.8 \mathrm{a}$ & $15.2 \mathrm{a}$ \\
High & $57.8 \mathrm{~b}$ & $33.8 \mathrm{a}$ & $13.7 \mathrm{~b}$ & $41.1 \mathrm{a}$ & $11.3 \mathrm{~b}$
\end{tabular}

${ }^{\mathrm{z}}$ Means followed by the same letters are not significantly different using the $t$ test for $P=0.05$, df $=18$.

Table 3. Effect of fruit location in the tree on the quality of 'Smoothee Golden Delicious' apples mechanically harvested from open-center trees.

\begin{tabular}{|c|c|c|c|c|}
\hline Treatment $^{2}$ & $\begin{array}{c}\text { Extra } \\
\text { Fancy } \\
(\%)\end{array}$ & $\begin{array}{c}\text { Fancy } \\
(\%)\end{array}$ & $\begin{array}{c}\text { Bruised } \\
(\%)\end{array}$ & $\begin{array}{l}\text { Cuts and } \\
\text { punctures } \\
(\%)\end{array}$ \\
\hline Apples below $135 \mathrm{~cm}(\mathrm{C})$ & $67.9 \mathrm{a}^{\mathrm{y}}$ & $16.3 \mathrm{a}$ & $9.7 \mathrm{a}$ & $6.1 \mathrm{a}$ \\
\hline Apples above $135 \mathrm{~cm}(\mathrm{O})$ & $55.8 \mathrm{~b}$ & $13.2 \mathrm{a}$ & $12.7 \mathrm{a}$ & $18.3 \mathrm{~b}$ \\
\hline
\end{tabular}

${ }^{\bar{z}} \mathrm{C}=$ fruit with an unobstructed path from point of attachment to mechanical harvester catching surface. $\mathrm{O}=$ path to catching surface obstructed by branch and/or other fruit.

${ }^{\mathrm{y}}$ Means followed by the same letters are not significantly different using the $t$ test for $P=0.05, \mathrm{df}=93$.

due to fewer cuts and punctures. However, even of the fruit with an unobstructed path to the catching surfaces, $>15 \%$ was nonmarketable.

In analyzing the detachment damage, only impact with the lowest amount of energy (first of four) produced a significantly higher percentage of fruit in the Extra Fancy category (Table 4). This was the result of having fewer apples in the bruised, and cuts and punctures categories. Any of the remaining impacts that were at a higher energy level damaged the harvested apples more. All higher impacts produced about the same amount of bruising, but the highest impacts produced more cuts and punctures.

The efficiency of the mechanical harvester was affected by cultivar, year, and, to a lesser extent, training system (Table 5). Preharvest losses were a serious limitation to mechanical harvesting, since $16 \%$ to $21 \%$ of the crop was lost before mechanical harvesting. Some of these losses were due to preharvest drop, but most lost apples were hanging too low and had to be picked by hand to allow machine movement through the orchard. If these apples had not been removed before mechanical harvesting, they would have been damaged, their weight would have caused limbs to droop, which would have interfered with fruit transfer, or the limbs would have damaged the catching surfaces. Even though a conscious effort was made to train the trees in the dormant season to keep the fruiting canopy high above the catching surface, by harvest time the canopy lowered due to increasing fruit weight, which interfered with machine movement. 'Bisbee Delicious' was a more compact upright tree than 'Golden Delicious' and, therefore, had less preharvest loss. Preharvest losses were greater on the open-center than the central-leader system because there was a higher percentage of the crop in the lower part of the tree canopy.

Removal efficiency was better with the spur cultivars than the nonspur cultivar. The more compact the tree structure, the better the energy transmission, which also explains the better removal 
from the open-center than the central-leader trees. Removal efficiency decreased in the third year of the study as the trees continued to grow and increase in size. Limb placement in a freestanding tree to obtain efficient fruit removal while providing sufficient structural support was difficult. It was difficult to effect removal on limbs that were weak or positioned perpendicular to the impact. We also found reliability problems with the massive trunk impactor. Although the trees were all headed fairly high due to differences in terrain, the impactor was often positioned near or on the ground, a position that decreased the delivery of impact energy to the upper tree structure.

Collection efficiency ranged from $90 \%$ to $95 \%$ and tended to decrease with a less compact tree canopy and as the fruiting canopy increased in size over time. Losses from the collecting surfaces were

Table 4. Effect of impact level on the quality of 'Smoothee Golden Delicious' apples mechanically harvested from modified open-center trees.

\begin{tabular}{lccccc}
\hline \hline & $\begin{array}{c}\text { Extra } \\
\text { Fancy } \\
(\%)\end{array}$ & $\begin{array}{c}\text { Fancy } \\
(\%)\end{array}$ & $\begin{array}{c}\text { Bruised } \\
(\%)\end{array}$ & $\begin{array}{c}\text { Cuts and } \\
\text { punctures } \\
(\%)\end{array}$ & $\begin{array}{c}\text { Fruit } \\
\text { removed } \\
(\mathrm{kg})\end{array}$ \\
\hline Impact & $43.9 \mathrm{~b}^{\mathrm{z}}$ & $18.2 \mathrm{a}$ & $20.6 \mathrm{~b}$ & $17.3 \mathrm{ab}$ & $65.6 \mathrm{a}$ \\
1 of 2-50\% $2-100 \%$ & $41.6 \mathrm{~b}$ & $17.3 \mathrm{a}$ & $15.5 \mathrm{~b}$ & $25.5 \mathrm{c}$ & $50.4 \mathrm{~b}$ \\
1 of 4-25\% & $69.4 \mathrm{a}$ & $13.0 \mathrm{a}$ & $6.9 \mathrm{a}$ & $10.7 \mathrm{a}$ & $21.8 \mathrm{c}$ \\
2 of 4-50\% & $48.5 \mathrm{~b}$ & $16.5 \mathrm{a}$ & $17.1 \mathrm{~b}$ & $17.8 \mathrm{ab}$ & $72.7 \mathrm{a}$ \\
3 of 4-75\% & $45.8 \mathrm{~b}$ & $14.8 \mathrm{a}$ & $16.6 \mathrm{~b}$ & $22.8 \mathrm{bc}$ & $45.2 \mathrm{~b}$ \\
4 of 4-100\% & $46.4 \mathrm{~b}$ & $13.6 \mathrm{a}$ & $13.6 \mathrm{ab}$ & $26.4 \mathrm{c}$ & $11.6 \mathrm{c}$
\end{tabular}

${ }^{\mathrm{z}}$ Means followed by the same letters are not significantly different using Duncan's multiple range test for $P=0.05, \mathrm{df}=44$. due to apples a) trapped on the inclined catching surface by low branches; b) lost around the trunk closure mechanism; c) lost as they were transferred from the inclined catching surface to the rollerdecelerator; d) thrown from the horizontal conveyor when handling a heavy fruit load or; e) lost off the edges of the catching surfaces.

Differences in removal efficiency and catching-surface efficiency produced similar results for machine efficiency. The spurtype 'Bisbee Delicious' was most efficiently harvested, with $>91 \%$ of the crop on the tree before harvest being removed, collected, and containerized. Least efficient was 'Smoothee Golden Delicious', with only $82 \%$ machine efficiency. Machine efficiency also decreased with time as the trees matured and yields increased.

Overall harvest system efficiency ranged between $64 \%$ and $77 \%$. That is, of the crop produced in the orchard, $23 \%$ to $36 \%$ was not harvested by the mechanical harvester under the tree-training and harvesting conditions described in our study. The only consistent success we had in harvesting a high percentage of fresh-marketquality apples was with compact spur-type 'Bisbee Delicious'. But even with 'Bisbee Delicious', when averaging 77\% harvest system efficiency and $80 \%$ of the harvested fruit in fresh-market grades (Extra Fancy and Fancy), mechanical harvesting would yield only a little $>60 \%$ of the fruit in the orchard for the fresh market. All other cultivars and tree types were even more unacceptable.

A commercially acceptable production system depends on obtaining sufficiently high yields of high-quality fruit that will provide the grower with a profit. Funt et al. (1992) indicated that $\approx 18 \mathrm{t} \cdot \mathrm{ha}^{-1}$ is required for profitable production at a planting density of 840 trees/ha, which is similar to our planting of 761 trees/ha. Our first measurable crop was produced by 'Delicious' (1.6 kg/tree) and 'Golden Delicious' ['Smoothee' (4.2 kg/tree) and 'Frazier

Table 5. Efficiency of an over-the-row mechanical harvester.

\begin{tabular}{|c|c|c|c|c|c|}
\hline Cultivar & $\begin{array}{l}\text { Preharvest } \\
\operatorname{lost}^{2}(\%)\end{array}$ & $\begin{array}{c}\text { Removal } \\
\text { efficiency }^{\mathrm{y}}(\%)\end{array}$ & $\begin{array}{c}\text { Collection } \\
\text { efficiency }^{\mathrm{x}}(\%)\end{array}$ & $\begin{array}{c}\text { Machine } \\
\text { efficiency }^{\mathrm{w}}(\%)\end{array}$ & $\begin{array}{c}\text { Harvest } \\
\text { system } \\
\text { efficiency }^{\mathrm{v}}(\%)\end{array}$ \\
\hline \multicolumn{6}{|l|}{ Main effects } \\
\hline \multicolumn{6}{|l|}{ Cultivar } \\
\hline Bisbee Spur Delicious & $16.3 b^{u}$ & $97.0 \mathrm{a}$ & $94.2 \mathrm{a}$ & $91.4 \mathrm{a}$ & $76.7 \mathrm{a}$ \\
\hline Fraizer Goldspur Golden Delicious & $20.6 \mathrm{a}$ & $93.5 \mathrm{~b}$ & $91.9 \mathrm{~b}$ & $85.9 \mathrm{~b}$ & $68.0 \mathrm{~b}$ \\
\hline Smoothee Golden Delicious & $20.4 \mathrm{a}$ & $88.9 \mathrm{c}$ & $92.2 \mathrm{~b}$ & $82.2 \mathrm{c}$ & $65.4 \mathrm{~b}$ \\
\hline \multicolumn{6}{|l|}{ System } \\
\hline Central leader & $17.0 \mathrm{~b}$ & $91.3 \mathrm{~b}$ & $92.4 \mathrm{a}$ & $84.4 \mathrm{~b}$ & $70.3 \mathrm{a}$ \\
\hline Open center & $21.2 \mathrm{a}$ & $95.0 \mathrm{a}$ & $93.2 \mathrm{a}$ & $88.5 \mathrm{a}$ & $69.9 \mathrm{a}$ \\
\hline \multicolumn{6}{|l|}{ Year } \\
\hline 1990 & $18.6 \mathrm{~b}$ & $96.0 \mathrm{a}$ & $95.4 \mathrm{a}$ & $91.5 \mathrm{a}$ & $74.7 \mathrm{a}$ \\
\hline 1991 & $17.4 \mathrm{~b}$ & $94.7 \mathrm{a}$ & $92.2 \mathrm{~b}$ & $87.3 \mathrm{~b}$ & $71.8 \mathrm{~b}$ \\
\hline 1992 & $21.2 \mathrm{a}$ & $88.7 \mathrm{~b}$ & $90.7 \mathrm{~b}$ & $80.6 \mathrm{c}$ & $63.7 \mathrm{c}$ \\
\hline \multicolumn{6}{|l|}{ Analysis of variance } \\
\hline Cultivar & $*$ & $* *$ & $* *$ & $* *$ & $* *$ \\
\hline System & $* *$ & $* *$ & NS & $* *$ & NS \\
\hline Cultivar $\times$ system & $* *$ & NS & NS & NS & $* *$ \\
\hline Year & $* *$ & $* *$ & $* *$ & $* *$ & $* *$ \\
\hline Cultivar $\times$ year & $* *$ & $* *$ & NS & $* *$ & $* *$ \\
\hline System $\times$ year & $*$ & NS & NS & NS & NS \\
\hline Cultivar $\times$ system $\times$ year & $*$ & NS & NS & NS & $* *$ \\
\hline
\end{tabular}

${ }^{\mathrm{z}}$ Fruit either picked by hand or natural drop before machine harvest.

y Of fruit on tree before harvest, amount removed by impact shaking.

${ }^{x}$ Of fruit removed by the impact shaker, amount collected by the catching surfaces.

${ }^{w}$ Of fruit on tree before harvest, amount removed and collected by mechanical harvester.

${ }^{\mathrm{v}}$ Of total crop in the orchard, amount removed and collected by mechanical harvester.

"Means are from raw data but transformed with arcsin transformation for analysis. Mean separation within columns by Duncan's multiple range test, $P=0.05, \mathrm{df}=90$.

Ns, ${ }^{* * *}$ Nonsignificant or significant at $P<0.05$ or 0.01 , respectively. 
Table 6. Yield of three apple cultivars and two training systems used to study a prototype over-the-row mechanical harvester.

\begin{tabular}{|c|c|c|c|c|c|}
\hline \multirow[b]{3}{*}{ Treatment $^{2}$} & \multicolumn{5}{|c|}{ Yield } \\
\hline & 1990 & 1991 & 1992 & $\begin{array}{c}\text { Cumulative } \\
\text { 1990-92 }\end{array}$ & \multirow{2}{*}{$\begin{array}{c}\text { Avg } \\
\text { 1990-92 } \\
\left(\mathrm{t} \cdot \mathrm{ha}^{-1}\right)\end{array}$} \\
\hline & \multicolumn{4}{|c|}{ (kg/tree) } & \\
\hline \multicolumn{6}{|l|}{$\overline{\text { Cultivar }}$} \\
\hline Bisbee Delicious & $12.4 b^{y}$ & $35.0 \mathrm{a}$ & $39.6 \mathrm{~b}$ & $87.8 \mathrm{c}$ & $22.4^{\mathrm{x}}$ \\
\hline Frazier Goldspur & $44.1 \mathrm{a}$ & $7.8 \mathrm{c}$ & $60.4 \mathrm{a}$ & $112.4 \mathrm{~b}$ & 28.5 \\
\hline Smoothee Golden Delicious & $43.8 \mathrm{a}$ & $26.3 \mathrm{~b}$ & $61.3 \mathrm{a}$ & $131.4 \mathrm{a}$ & 33.4 \\
\hline \multicolumn{6}{|l|}{ Training system } \\
\hline Central leader & $35.1 \mathrm{a}$ & $27.2 \mathrm{a}$ & $57.3 \mathrm{a}$ & $119.6 \mathrm{a}$ & 30.5 \\
\hline Open center & $31.8 \mathrm{a}$ & $18.8 \mathrm{~b}$ & $50.2 \mathrm{a}$ & $101.4 \mathrm{~b}$ & 25.7 \\
\hline \multicolumn{6}{|l|}{ Analysis of variance } \\
\hline Cultivar & $* *$ & $* *$ & $* *$ & $* *$ & \\
\hline System & NS & $* *$ & NS & $* *$ & \\
\hline Cultivar $\times$ system & NS & $*$ & NS & NS & \\
\hline
\end{tabular}

zTrees planted in 1985. All trees initially trained as central leader trees; conversion to open-center form began in 1989.

${ }^{y}$ Means are from raw data, but data transformed with arcsin transformation for analysis. Mean separation within columns for cultivar by Duncan's multiple range test and for training systems by $t$ test, $P=0.05$, $\mathrm{df}=30$.

${ }^{x}$ Average yield per hectare calculated from average yield per tree from 1990 to 1992 and 761 trees/ha.

ns,,$* *$ Nonsignificant or significant at $P=0.05$ or 0.01 , respectively.

Goldspur' $(6.7 \mathrm{~kg} /$ tree)] trees in their fourth leaf (1988). Lowtemperature injury during bloom severely reduced yield of all trees in 1989. Mean yield data for main plot and subplot effects for 1990 (sixth leaf) to 1992 (eighth leaf) are given in Table 6. Average yields per hectare exceeded a profitable production level (Funt et al., 1992) for all cultivars and training systems from 1990 to 1992. 'Smoothee Golden Delicious' had the highest cumulative yield, followed by 'Frazier Goldspur' and 'Bisbee Delicious', which had significantly lower cumulative yields over the 3 years of the study. Reduced yields for 'Golden Delicious' trees in 1991 may have been the result of poor thinning response in 1990. Yields per tree were significantly lower for open-center trees than central-leader trees in 1991, as were cumulative yields for 1990 to 1992. These results contrast work by Lakso et al. $(1978,1989)$, who reported no difference in yield from central-leader and open-center 'McIntosh' trees. There was a significant cultivar $\times$ system interaction for yield in 1991, which was probably associated with the overall low yield for 'Frazier Goldspur' that year. Our studies indicate that, while open-center training of freestanding semidwarf apple trees may reduce yields below those of central-leader trees, yields were still well above minimum levels for profitability.

Our 1992 studies showed that fruit with an unobstructed path to the catching surface removed with a very low energy level had the best chance of being harvested without damage. Robinson et al. (1990) showed good potential for mechanically harvested 'Empire' apples grown on a Y-trellis. Further research efforts will concentrate on growing trees supported by a narrow Y-trellis with fruit removal effected by a limb impactor.

\section{Literature Cited}

Berlage, A.G. 1973. Apple harvesting trials with oscillating air jets. Trans. Amer. Soc. Agr. Eng. 16:460-461.

Berlage, A.G. 1982. Mechanical apple harvester with sorting capability. Trans. Amer. Soc. Agr. Eng. 25:912-918.

Brown, G.K., D.E. Marshall, B.R. Tennes, D.E. Booster, P. Chen, R.E. Garrett, M. O'Brien, H.E. Studer, R.A. Kepner, S.L. Hedden, C.E. Hood, D.H. Lenker, W.F. Millier, G.E. Rehkugler, D.L. Peterson, and L.N. Shaw. 1983. Status of harvest mechanization of horticultural crops. Amer. Soc. Agr. Eng., St. Joseph, Mich. SP 3-83, p. 78.
Cain, J.C. 1971. Effect of pruning and tree size on within-tree bruising on mechanically harvested 'McIntosh' apples. J. Amer. Soc. Hort. Sci. 96:91-93. Diener,R.G. and R.E. Adams. 1974.Economic evaluation of the butterfly orchard design for mechanical harvesting. W.Va. Univ. Agr. Expt. Sta. 221:1-15.

Funt, R.C., T.A. Baugher, H.W. Hogmire, and W.C. Kleiner. 1992. Profitability of different apple orchard systems in the eastern United States. OARDC Hort. Dept., Wooster, Ohio. Ser. 624

Heinicke, D.R. 1975. High density apple orchards-planning, training, and pruning. U.S. Dept. of Agr. Hdbk. 458.

LaCroix, D. 1989. Ag laborers wanted. The Grower 22(10):16, 18, 22-23.

Lakso, A.N. 1984. Principles of tree design for production and mechanical harvest. Great Lakes Fruit Growers News 23(4):50-52.

Lakso, A.N., W.F. Millier, R.A. Pellerin, and S.G. Carpenter. 1978. Conversion of central leader apple trees for improved mechanical harvest. J. Amer. Soc. Hort. Sci. 103:284-287.

Lakso, A.N., T.L. Robinson, and S.G. Carpenter. 1989. The palmette leader: A tree design for improved light distribution. HortScience 24:271-275.

Markwardt, E.D., H.A. Longhous, and J. Maynard. 1966. Effects of tree structure on damage to apples during mechanical harvest. Amer. Soc. Agr. Eng. paper no. 66-136.

McHugh, C.M., B.K. Webb, and C.E. Hood. 1977. A small, single frame peach and apple harvester. Amer. Soc. Agr. Eng. paper no. 77-1526.

Miller, S.S. and D.L. Peterson. 1989. Training semi-dwarf apple trees for over-the-row mechanical harvesting of fresh market quality fruit. Acta Hort. 243:111-115.

Millier, W.F., G.E. Rehkugler, R.A. Pellerin, and J.A. Throop. 1973. Tree fruit harvester with insertable multilevel catching system. Trans. Amer. Soc. Agr. Eng. 16:844-850.

Peterson, D.L. and S.S. Miller. 1989a. Advances in mechanical harvesting of fresh market quality apples. J. Agr. Eng. Res. 42:43-50.

Peterson, D.L. and S.S. Miller. 1989b. Harvesting alternatives. Proc. Oregon State Hort. Soc. 80:80-88.

Peterson, D.L. 1992a. Harvest mechanization for deciduous tree fruits and brambles. HortTechnology 2:85-88.

Peterson, D.L. 1992b. Roller decelerators-Catching surface for damage susceptible tree fruits. Applied Eng. Agr. 8(3):277-280.

Robinson, T.L., W.F.Millier,J.A. Throop, S.G.Carpenter, and A.N.Lakso, 1990. Mechanical harvestability of Y-shaped and pyramid-shaped 'Empire' and 'Delicious' apple trees. J. Amer. Soc. Hort. Sci. 115:368-374.

Whitney, J.D., N. Mohsenin, and L.D. Tukey. 1963. An elevating mechanical harvester for apple trees trained to the plateau system. Proc. Amer. Soc. Hort. Sci. 83:175-184. 